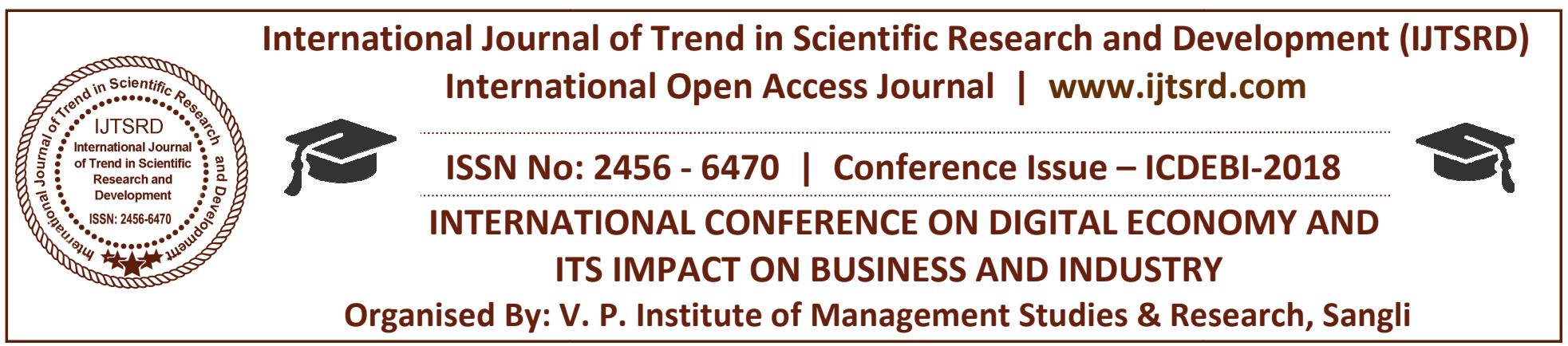

\title{
Resource Sharing and Networking in Libraries
}

\author{
Mrs. Anuradha A. Kumbhar \\ B.Sc., PGDCA, MCA, MLIS, UGC NET-SET LIS, \\ Library Clerk, CSIBER, Kolhapur, Maharashtra, India
}

\begin{abstract}
This paper gives the information about resource sharing and network system which is useful in the library daily work. Now days in era of the ICT, the computers make very much impact on every area in our daily life. Library is also not an objection from that. Information explosion is so huge in all area of studies. On the basis of that all / each and every library cannot have that much space and money to store all the information available everywhere. As per the ICT development growth, the libraries have to cop up with the new ideas and techniques available. Resource sharing is the best solution for use of information available in a huge amount. Again, the resource sharing is supported by networking in libraries. With the help of networked system, libraries can share knowledge, equipment etc. on online basis. Library material is available in print and digital format which is used by different users as per their needs. Resource sharing and networking plays a very supportive role in all the areas of library work. On the other hand, libraries can improve their services, performance, and operations related to user's area of studies.
\end{abstract}

KEYWORD: Resource Sharing, Objectives of Resource sharing, Networking, INFLIBNET, DELNET

\section{INTRODUCTION}

In the era ICT, the information is available in a digital format such as audio, video, text file etc. Resource sharing is based on co-operation principles which help in storing, accessing information in different areas of studies. 'Five Laws of Library Science' the book written by Dr. S. R. Ranganathan has also highlighted about resource sharing and networking of library material and information on library co-operation.
Networking and resource sharing is supporting in usefulness and betterment of library services and operations. Five laws of library science play an important role in daily work of libraries. University Grand Commission (UGC) and other educational bodies also suggest and support for the networking of college libraries for resource sharing in India. In Developing countries like India networking of college libraries under umbrella of universities has been widely supported in different levels of development as per ICT requirements tools and techniques. INFLIBNET and NAAC are also highlighted / stressed on networking of university and college libraries in providing information environment of affiliated institutions. There is growth in the information in published document in a recent era in both print and digital form. As a result of this, no any single library can able to get hold of process to store all document that user need as per his subject. "It is difficult to any single library to get your hands on even one percent of the total document published in the world" (Kent 1978)

Some of the reasons for the requirement of resource sharing and networking are as follows:

a) Information Explosion

b) Increase in literature in both print and digital format

c) Wide range of users in all areas

d) Different areas of specialization

e) Declining funds

f) Cost per publication

g) Variety of needs for literature

h) Required environment for ICT - Limitations for libraries 


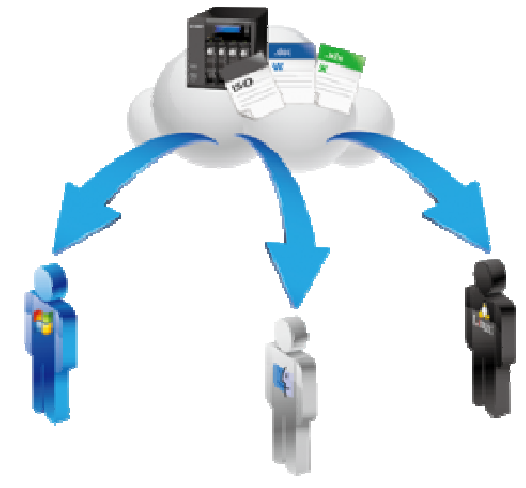

Interlibrary Loan (ILL) is the initial activity in libraries and information centers to support resource sharing. At the local level union catalogue is used as support to resource sharing. In this case only books and library material is taken into concern. Resource sharing is now taken place by library networks as the ICT application used by libraries. The libraries are located on far places from each other the computer networks are used to connect them and communication technology is used for resource sharing. Thus ICT plays an important role in betterment of resource sharing universally. WWW and internet technology added benefits to networking. Different organizations share the access to Eresources by developing consortium and economic knowledge base in limited funds.

\section{RESOURCE SHARING:}

According to John Fetter man, "any and all of the materials, functions, and services which constitute a modern library system, it is amalgamation of people (manpower), processes, ideas, materials, and money which form the substance of a library and can be described as its resources".

The American Library Association (ALA) Seminar on Network and Multi-type Library Co-operation defines the term resource sharing as "The co-operative structures, which cross jurisdictional, institutional, and often political boundaries to join in a common enterprise, several types of libraries - academic, special, and public".

Since 1960, library professionals are using the term resource sharing. Resource sharing can be supported libraries such as co-operative acquisition, cataloguing, classification. Computerized systems overcome limitations such as distance, language, time etc. two way co-operation is needed from the participating libraries in resource sharing and networked process such as developing the collection on shared basis.
Now a day users are more demanding and their expectation from the libraries are above the collection. For satisfying the user needs as their requirement staff have to be more interactive with the latest knowledge and updates related new areas of interest and requirements in best possible way.

\section{OBJECTIVES OF RESOURCE SHARING:}

The main objective of resource sharing is maximum services at minimum cost and creating such an environment that serves to meet all needs of user in available materials. Material means reading material of all types, formats acquisition, cataloguing, storage and preservation. Following are the objectives for better sharing:

a) To give best services to user

b) To serve with more coverage and facilities

c) To avoid duplication

d) To share experiences

e) To face financial crisis

f) To encourage interaction

g) To give wider access to users

h) To improve ILL productivity and control ILL cost

i) To offer high quality library and information support services

j) To reduce communication gap between the libraries

In the management institution following areas for resource sharing such as collection update, inter library loan, reference services, membership, content page services, centralized processing, human resources, expertise and facilities, database creation, union catalogue, training and software.

\section{NETWORKING IN LIBRARIES:}

Networking is a process that fosters the exchange of information and ideas among individuals or groups that share a common interest. It may be for social or business purposes. Professionals connect their business network through a series of symbolic ties and contacts.

A network connects computers, mobile phones, peripherals, and even IoT devices. Switches, routers, and wireless access points are the essential networking basics. Through them, devices connected to your network can communicate with one another and with other networks. 


\section{Computer network diagram}

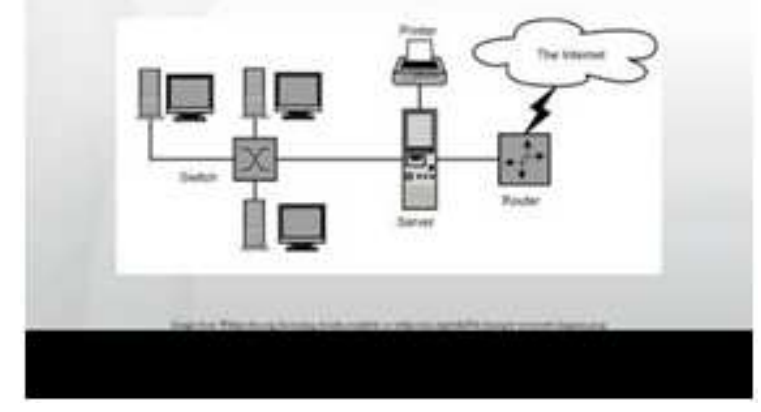

National commission on libraries and information science National program in 1975 defines network as "Two or more libraries or other organization engaged in common pattern of interaction exchange through communication for some functional purpose. All libraries are having different type of reading material as per their requirement so that libraries having an agreement for network system and exchange of material as their own rules and regulations. For giving facilities to each other libraries are using computers and telecommunication as a tool for communication between them." For communication between the computers systems in the network there are different $\mathrm{TCP} / \mathrm{IP}$ protocols are available in the internet facilities. For connecting computers to each other types of topologies are there such as bus, star, mesh etc. There are number networks such as LAN, WAN, MAN, and Wireless networks with help of which the distance between the libraries or organization has no matter for communication. Data is available in the form like multimedia, hyper-text which can be available to the user in fraction of minutes. Gopher, email, telnet, FTP and WWW are the user friendly tools available for processing and accessing information. The agreement of co-operations is made by libraries for the purpose of resource sharing of each other material. In ICT era libraries are using computers and automated their library services using software. Library material is present initial in the form of books, journals, magazines in print but now eresources are available such as e-books, e-journals, enewspapers. Because of the networked systems the computer can use space, database, program and printer beyond the distance, language cost time.

In India for supporting the concept of resource sharing and networking in libraries some major library networks are working for betterment of libraries:
Information and library network (INFLIBNET): This is autonomous Inter University Center (IUC) of University Grand Commission (UGC) of India under Ministry of HRD in June 1996. INFLIBNET is involved in modernizing university libraries in India and connecting them as well as information centers in the country through a nationwide high speed data network using the state-of-art technologies for the optimum utilization of information. INFLIBNET is set out to be a major player in promoting scholarly communication among academicians and researchers in India. It gives support to the academic and research institution in automation of libraries, creating union catalogue of serials, thesis, books, monographs, creating database of projects.

Developing Library Network (DELNET): In 1988, DENET was started with financial support by National Information System in Science and Technology (NISSAT). National Information Center (NIC) of the planning commission, Government of India presently supports activities of DELNET. DELNET gives membership to various libraries including universities, colleges, government department and provide technical assistance to them for creating and maintaining bibliographic databases, serials, union catalogue preparation, abstracting services, inter library loan etc.

Management Library Network (MANLIBNET), Ahmadabad Library Network (ADINET), National Information Center Network (NICNET), INDONET, Education and Research Network (ERNET), Calcutta Library Network (CALIBNET) etc. are the number of library networks available in India to support networks. These networks help in resource sharing, staff training, ILL etc. In this way, ICT development changes the working of the library. The libraries using the automated software help each other to ful fill the requirement of the user which is the first priority of the library. As per Dr. S. R. Ranganathan five laws of library science by using the new technologies like resource sharing and networking libraries can satisfy all the five laws such a way that satisfying user need in minimum time and cost.

\section{CONCLUSION:}

As the ICT is emerged in the library system, the new technology helps us for faster \& accurate work to be done. The main reasons of resource sharing in libraries are information / knowledge explosion, increase in library users, library services, acquisition 
problem, economic resources, web based resource sharing. Library network ensure resource sharing manage number of libraries by co-operative nature which help in collection development and reduce duplication of work. The main purpose of library network is to make available network based services to users, document delivery services, bibliographic information services and human resource development.

\section{REFERENCE:}

1. M. Muthu "Resource sharing in Libraries: A Vital role of consortia" International Research: Journal of Library and Information Science, Vol.3, No.1, Apr 2013

2. Manoj Kumar Sinha and Kishor Chandra Satathy "Resource sharing and Library Networks in India" Indian Journal of Information, Library and Society(IJILIS), Vol.21, No.1-2, Jan-Jun 2008, Page 75-84, ISSN 0971-4286

3. Dr. D. S. Thakur and K. S. Thakur "Resource Sharing and its necessity in the changing environment" http://www.nuepa.org/libdoc/elibrary/articles/2000dst.pdf

4. Dr. Baljinder Kaur "Resource sharing and Networking" http://epgp.inflibnet.ac.in/epgpdata/uploads/epgp_ content/library_and_information_science/academi c_libraries/15a._resource_sharing,_networks_\&_consortia2/et/2013_et_15-a.pdf
5. Dr. Baljinder Kaur "Library Networking and Consortia in India" http://epgp.inflibnet.ac.in/epgpdata/uploads/epgp_ content/library_and_information_science/academi c_libraries/15-

b._library_networks_and_consortia_in_india/et/44 39_et_15-b.pdf

6. P. R. Rau and H. Raghav Rao "INDONET: A PUBLIC SERVICE DATA NETWORK IN INDIA"

https://flora.insead.edu/fichiersti_wp/Inseadwp199 3/93-18.pdf

7. https://www.researchgate.net/publication/2679632 47_RESOURCE_SHARING_AMONG_LIBRAR IES_IN_DIGITAL_ERA_ROLE_OF_CONSORT IA

8. http://shodhganga.inflibnet.ac.in/bitstream/10603/ 3785/15/15_chapter\%205.pdf

9. http://shodhganga.inflibnet.ac.in/bitstream/10603/ 50907/13/13_chapter\%206.pdf

10. https://www.researchgate.net/publication/3165143 96_Resource_Sharing_Library_Networks_in_Indi a

11. http://www.academia.edu/6117628/Resource_Sha ring_through_Networking_Indian_Scenario

12. https://www.inflibnet.ac.in/

13. https://en.wikipedia.org/wiki/INFLIBNET_Centre 14. http://delnet.nic.in/ 